\title{
Chemical composition and activity of a biofilm during the start-up of an airlift reactor
}

\author{
F.A. Lopes, M.J. Vieira and L.F. Melo \\ Centro de Engenharia Biológica - IBQF, Universidade do Minho, 4700-057 Braga, Portugal
}

\begin{abstract}
For the successful operation of a biofilm reactor, it is important to characterise the fixed biomass, its activity and composition. The purpose of this research was to monitor the biofilm characteristics of an airlift reactor, namely its composition in terms of exopolymers (polysaccharides and proteins), attached biomass, thickness, total proteins, as well as its activity in terms of substrate consumption rates. During the early phases of biofilm development, a high exopolymer production was observed, which helped in promoting the initial cell adhesion. The high turbulence with strong abrasive conditions might also trigger the excretion of those polymers. Low levels of extracellular proteins were detected, showing that the proteins in the biofilm were mainly intracellular. The biofilm accumulation on the carrier was accompanied by an increased biological activity; however, at the end of the experiment, the specific substrate consumption rate decreased, probably because of a reduction of the cell density within the biofilm.
\end{abstract}

Keywords Airlift reactor, biofilm, biofilm activity, biofilm composition, Pseudomonas fluorescens

\section{Introduction}

Bacterial growth on surfaces is a phenomenon occurring in a high variety of environments, both in nature and in industry. It is an immobilization process that can be exploited to human advantage, such as in bioreactors applied to wastewater treatment. Immobilization favours high biomass concentrations, and therefore high volumetric conversion rates.

In airlift reactors, biofilms are formed on small suspended particles such as basalt or sand grains, which are kept in suspension by an air stream. There are some important differences between biofilm formation in an airlift reactor and in conventional biofilm systems, such as, (i) relatively higher specific surface area, (ii) turbulent flow conditions, (iii) spherical biofilm geometry (Heijnen et al., 1992). Due to the large carrier surface area in such a reactor (up to 2000 to $3000 \mathrm{~m}^{2} / \mathrm{m}^{3}$ ), high volumetric conversions can be obtained (Tijhuis et al., 1994). Furthermore, high oxygen transfer rates are possible because of the sparged air and the turbulent conditions in the reactor. This technology is thus potentially capable of achieving high active biomass concentrations in the reactor (Tijhuis et al., 1992).

Biofilm dry mass is mainly composed by two components, microbial cells and extracellular polymers (EPS). This polymeric matrix, often with a large polysaccharide content, is important to biofilm development. The irreversible adhesion of bacterial cells to the support is greatly determined by the physical properties of the macromolecules at the cell surface, the formation of bridges of extracellular polymers being responsible for anchoring the cells to the substratum.

For a stable and reliable operation of a biofilm airlift suspended reactor, a more detailed knowledge of the biofilm characteristics such as its thickness, composition and activity is required. Since these properties are affected by the initial conditions of biofilm development, the purpose of this work was to monitor its characteristics during the start-up of an airlift reactor.

\section{Materials and methods}

Pseudomonas fluorescens, a Gram-negative bacteria, was used as a biofilm producer in a concentric tube airlift reactor (Table 1 and Figure 1) containing basalt particles as support for biofilm growth. 


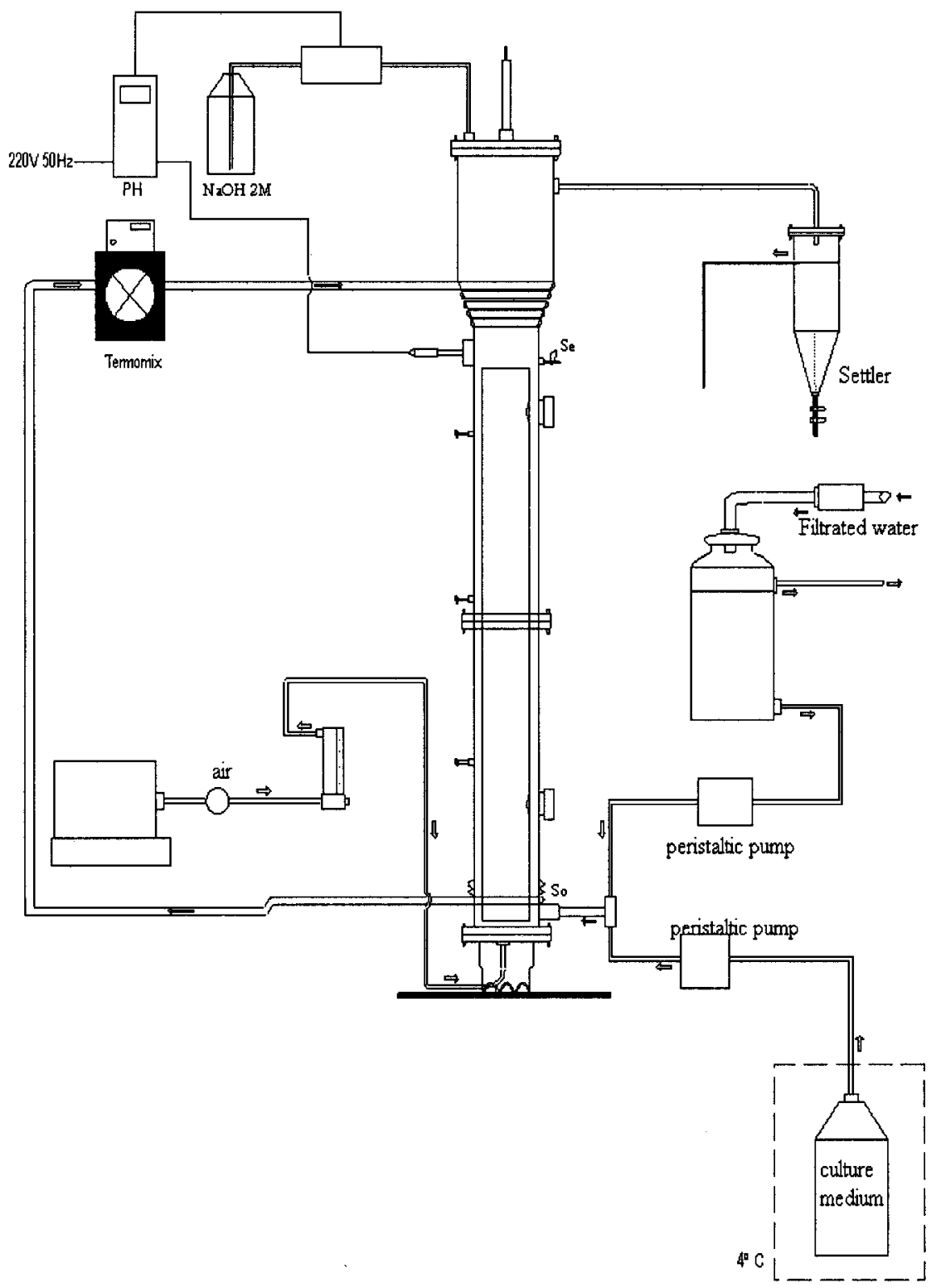

Figure 1 Schematic representation of the airlift reactor

Table 1 Dimensions of the airlift reactor

\begin{tabular}{lllll}
\hline $\begin{array}{l}\text { Working volume } \\
(\mathrm{L})\end{array}$ & $\begin{array}{l}\text { Total reactor } \\
\text { height }(\mathbf{m})\end{array}$ & $\begin{array}{l}\text { Riser internal } \\
\text { diameter }(\mathbf{m m})\end{array}$ & $\begin{array}{l}\text { Downcomer internal } \\
\text { diameter }(\mathbf{m m})\end{array}$ & $\begin{array}{l}\text { Riser height } \\
(\mathbf{m})\end{array}$ \\
\hline 5.9 & 1.08 & 43 & 74 & 0.89 \\
\hline
\end{tabular}

All through the experimental run a carrier concentration of $50 \mathrm{~g} / \mathrm{L}$ was maintained in the reactor. The mean equivalent diameter and the density of the particles were $435 \mu \mathrm{m}$ and $3067 \mathrm{~kg} / \mathrm{m}^{3}$, respectively. 
Air was sparged from the bottom of the inner tube of the reactor (riser) through a sintered glass filter. The superficial air velocity in the riser was $5.1 \mathrm{~cm} / \mathrm{s}$, corresponding to an air flow of about $4.5 \mathrm{~L} / \mathrm{min}$ whereas the liquid superficial velocity was $0.26 \mathrm{~m} / \mathrm{s}$.

The temperature and $\mathrm{pH}$ in the reactor were maintained at $22^{\circ} \mathrm{C}$ and 7 , respectively. The reactor was inoculated with a batch culture, the culture medium consisting of $5 \mathrm{~g}$

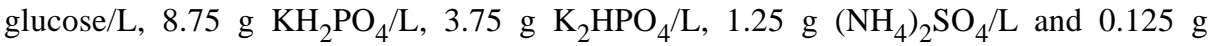
$\mathrm{MgSO}_{4} \cdot 7 \mathrm{H}_{2} \mathrm{O} / \mathrm{L}$.

At the beginning the reactor was set in batch mode for two days in order to promote the initial adhesion of microorganisms to the particles. Then, continuous operation was started with an inlet glucose concentration of $53 \mathrm{mg} / \mathrm{L}$ and an initial dilution rate of $0.1 \mathrm{~h}^{-1}$, which is lower than the maximum growth rate of Pseudomonas fluorescens $\left(\mu_{\max }=0.30 \mathrm{~h}^{-1}\right.$, obtained in batch conditions). After this adjustment period, the dilution rate was stepwise increased to $1 \mathrm{~h}^{-1}$.

In the course of the test, the glucose concentration was measured in the influent and effluent streams using the GOD-POD method (Sera-Pack GOD/POD Method - Ames) in order to determine the surface glucose reaction rate $\left(r_{f a}\right.$, mg of glucose consumed per time unit and unit of area of carrier) and the specific glucose removal rate $\left(q_{S}\right.$, mg of glucose consumed per time unit and mass unit of volatile biofilm).

Suspended biomass was determined in the effluent as Total Suspended Solids (TSS).

To determine the immobilized biomass, biofilm particles were removed from the reactor, dried at $103^{\circ} \mathrm{C}$ and then placed in a furnace at $550^{\circ} \mathrm{C}$ for 2.5 hours. Biofilm mass (volatile mass) was estimated as the difference between the dried and the burned masses. The mass of the support particles was determined by washing the burned sample several times with distilled water to remove ashes and by placing it in an oven to dry. Attached volatile biomass was expressed as $\mathrm{mg}_{\text {volatile biofilm }} / \mathrm{g}_{\text {Basalt }}$.

The exopolymers were extracted with glutaraldehyde according to a method adapted from Azeredo et al. (1998). Biofilm samples were placed in an Erlenmeyer flask with $20 \mathrm{~mL}$ of glutaraldehyde $3 \%$ and kept in an orbital shaken incubator (80 rpm) at room temperature for at least two days. Afterwards, the supernatant was filtered through a $0.20 \mu \mathrm{m}$ pore size filter and dialysed against distilled water for three days. This procedure was done twice. Thereafter, polysaccharides were determined by the method of Dubois et al. (1956) using glucose as the standard and extracellular proteins were estimated according to the method of Lowry et al. (1951) developed by Sigma (procedure 5656) that uses the bovine serum albumin (BSA) as the standard.

The sample used for the determination of total proteins was first sonicated (Vibracellmodel CV 600, power $30 \mathrm{~W}$ and $12 \mathrm{~min}$ in $20 \mathrm{~s}$ cycles) before applying the method of Lowry et al. (1951). The extracellular and total proteins were expressed as $\mathrm{mg} \mathrm{protein} / \mathrm{g}_{\mathrm{volatile} \mathrm{biofilm}}$ and polysaccharides were expressed as $\mathrm{mg}_{\text {glucose }} / \mathrm{g}_{\text {volatile biofilm }}$.

When steady state was reached in the reactor, particle projected areas $\left(A_{2}\right)$ and perimeters $\left(P_{2}\right)$ of the biofilm covered particles were measured using an image analysis system. After being washed to remove nonadherent biomass, biofilm samples were observed by means of a lens and a camera connected to the computer system. The projected area and the perimeter of about 600 biofilm pellets were determined. Afterwards, these particles were placed in a furnace in order to remove the biomass. Then they were submitted to the same procedure to determine the corresponding projected area $\left(A_{1}\right)$ and perimeter $\left(P_{1}\right)$ without biofilm.

The following expression was used to estimate biofilm thickness $(\mathrm{L})$ :

$L=\left(A_{2}-A_{1}\right)\left(\frac{P_{1}+P_{2}}{2}\right)^{-1}$ 
The loss of the carrier material from the reactor due to the sampling was compensated by the addition of new basalt particles.

\section{Results and discussion}

By applying a dilution rate of $1 \mathrm{~h}^{-1}$, the growth of suspended biomass was prevented (Figure 2). Data from this figure clearly show an increase in biofilm volatile mass with time to finally attain a rough steady-state value. In this situation, the detachment rate balanced the growth rate of the biomass on the carrier and the amount of attached biomass remained constant.

This figure also indicates a decrease in suspended biomass concentration in the effluent with time, as expected. At high dilution rates $\left(D \geq 0.5 \mathrm{~h}^{-1}\right)$, the suspended biomass can be regarded as recently detached biofilm mass. Biofilm development in such a system is strongly influenced by liquid shear and abrasion, the latter being caused by particle-particle and particle-reactor wall interactions. When a higher number of bare carrier particles becomes covered with biofilm, their surface becomes smoother (no sharp edges), the impact of the abrasion mechanisms is lowered and biofilm detachment is reduced.

Image analysis measurements $\left(A_{1}=0.2243 \mathrm{~mm}^{2} ; A_{2}=0.2912 \mathrm{~mm}^{2} ; P_{1}=1.7629 \mathrm{~mm}\right.$; $P_{2}=1.9912 \mathrm{~mm}$ ) gave an average steady-state biofilm thickness of about $36 \mu \mathrm{m}$. The biofilm was thin, in spite of an easily degradable carbon source (glucose). The strong hydrodynamic forces in the reactor seemed to be the prevailing mechanism in the biofilm formation by limiting its thickness.

Figure 3 indicates an increase in biofilm extracellular proteins and polysaccharides at the beginning of the experiment, then a decrease, to finally reach a lower and more stable value around day 20. The high extracellular polymer production in the initial period of biofilm formation corresponds to the initial cell adhesion, in particular when the carrier surface is only partially covered by isolated microcolonies. Furthermore, at the beginning with higher shear stress and abrasion levels, those polymers can play an important role in biofilm cohesion. Since the abrasion effect of particle collisions will diminish during the run, the exopolymers production per mass unit of volatile biofilm will tend to decrease.

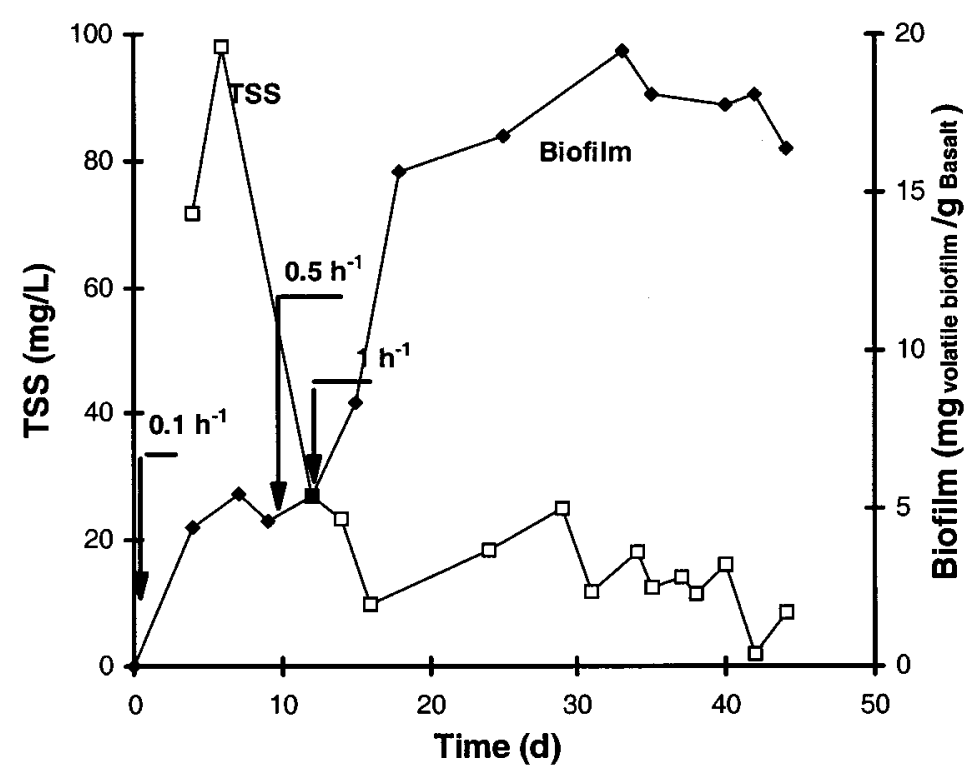




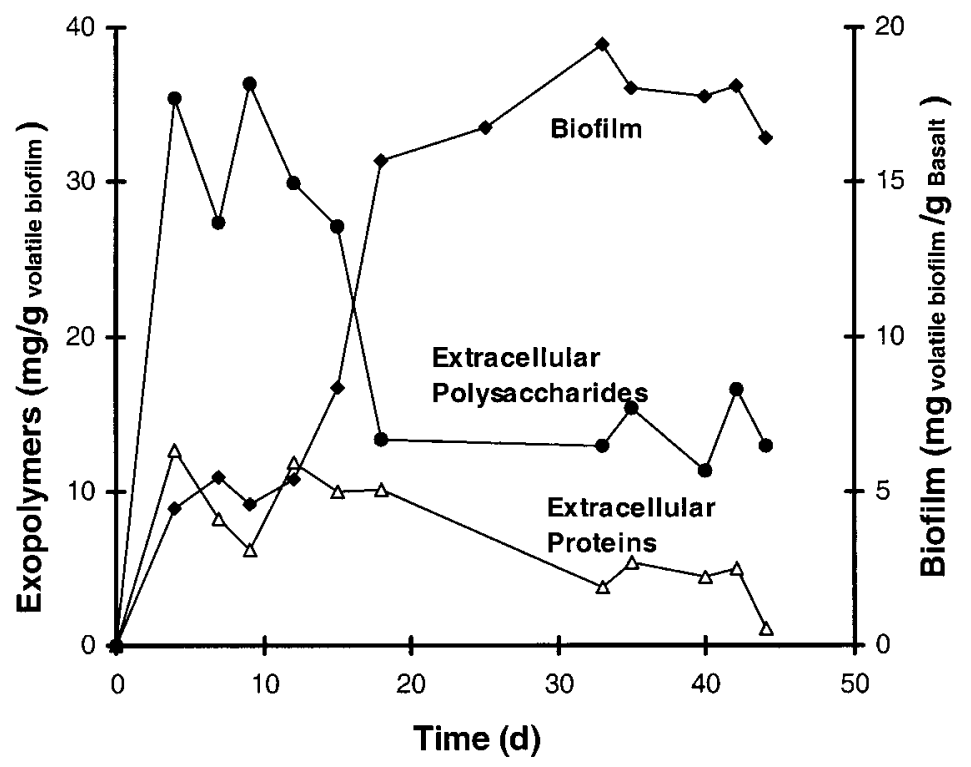

Figure 3 Extracellular polysaccharides $\left(\mathrm{mg}_{\text {glucose }} / \mathrm{g}_{\text {volatile biofilm }}\right)$ and proteins $\left(\mathrm{mg}\right.$ protein $\left./ \mathrm{g}_{\text {volatile biofilm }}\right)$ as function of time of operation

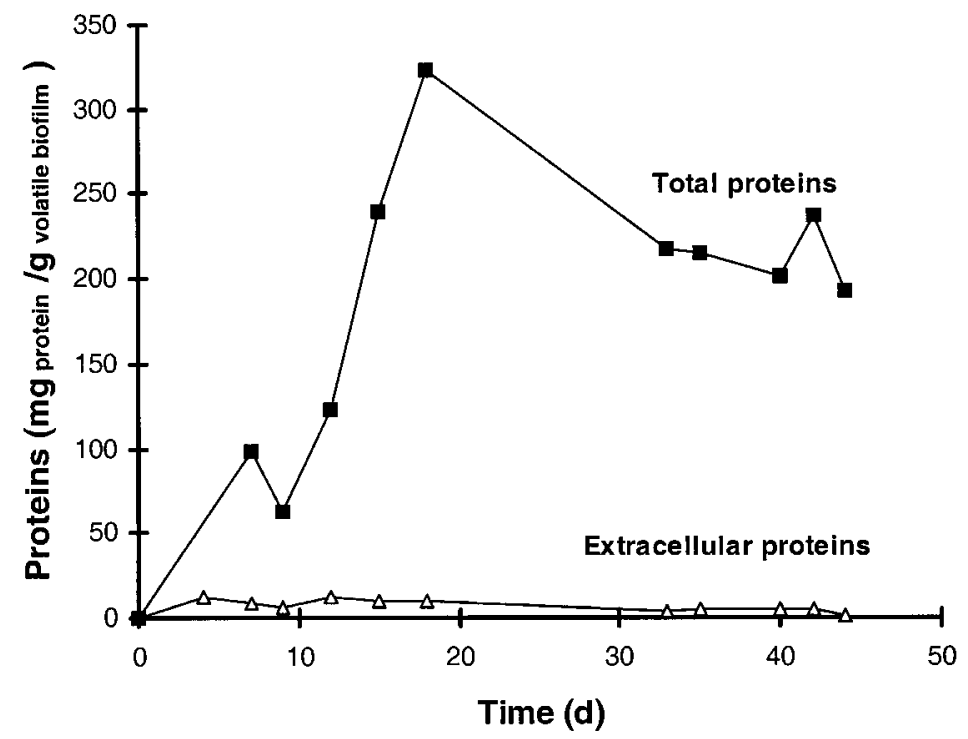

Figure 4 Total and extracellular proteins as function of time of operation

The total protein content (Figure 4) was much higher than the extracellular proteins, which means that biofilm proteins were mainly intracellular, in the present case.

It should be noted that until day 10 (i.e., before the dilution rate was increased up to $0.5 \mathrm{~h}^{-1}$ ), the substrate consumption in the reactor was due not only to the biofilm but also to the significant amount of suspended biomass (Figure 5 and 2).

Between days 10 and 16-18, the substrate consumption rates continued to increase (Figure 5), meaning that the number of active cells on the support augmented. This is in agreement with the data in figure 4 showing an increase in total proteins (related to the mass of cells). As reported by other authors (Tijhuis et al., 1994), three stages of the biofilm formation were visually observed in this run: first, only the bare carrier, then some 


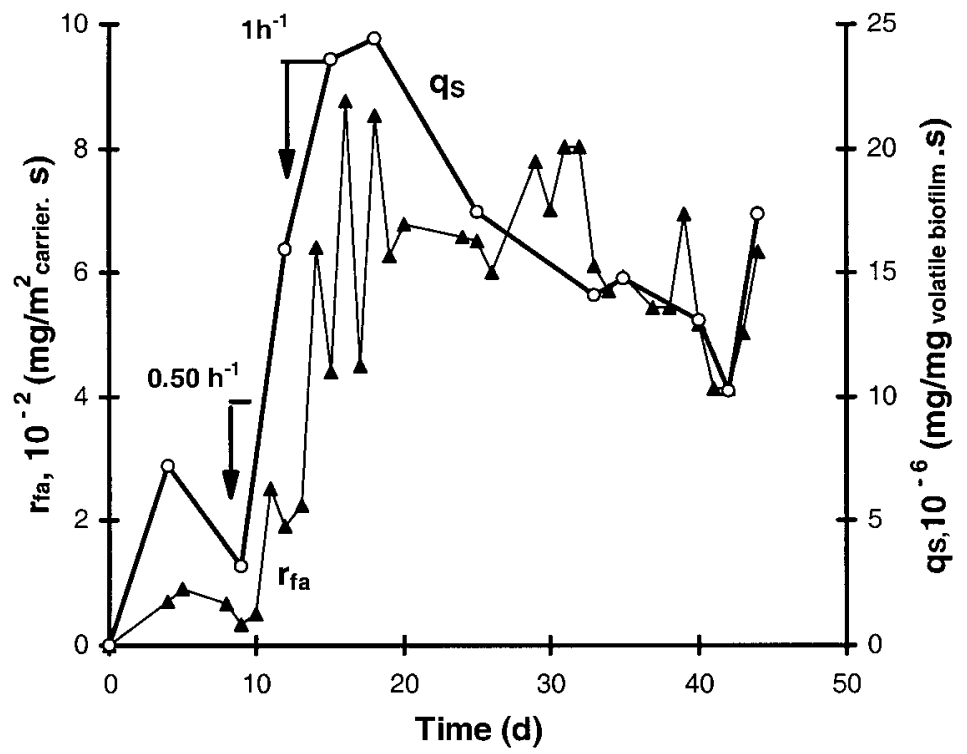

Figure 5 Surface glucose reaction rate $\left(r_{f a}\right)$ and specific glucose removal rate $\left(q_{S}\right)$ as function of time of operation

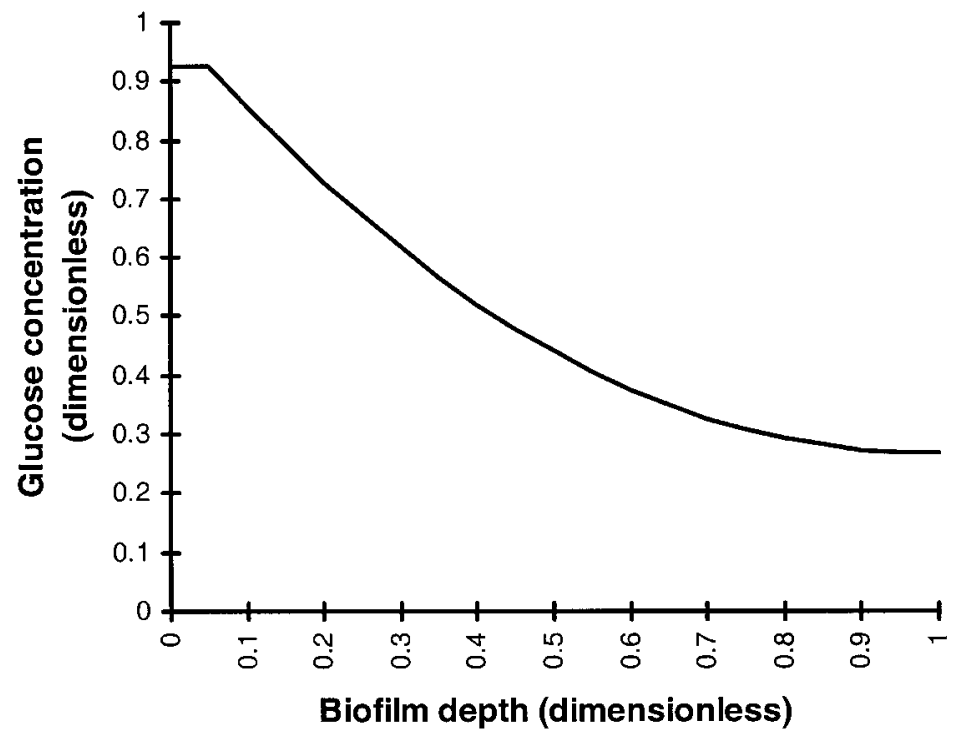

Figure 6 Glucose concentration profile (average values) predicted by a diffusion-reaction model

microcolonies or "patchy" biofilm on the carrier surface and, finally (after about 20 days), a continuous biofilm surrounding the support. Therefore, the increase in the consumption rates was probably the result of the spreading of new colonies on the carrier surface.

The specific consumption rate decreased after days 16-18. Since in such a thin biofilm $(36 \mu \mathrm{m})$ the existence of inactive zones is not expectable, that decrease can be explained by a reduction in the relative cell density within the biofilm. At the beginning, the biofilm is basically constituted by cells and some polymers, which means that almost all the attached biomass may produce new cells and exopolymers. The first phase corresponds to the 
biofilm mass (the cells) can produce more cells and exopolymers, so the fraction of cells in the biofilm mass is diminished. Using total proteins (approximated as intracellular proteins, in the present case) to assess the amount of cells, a reduction in the cell content per mass unit of biofilm can indeed be detected during this period of time (Figure 4). This reduction in cell density resulted in lower specific consumption rate, as shown in Figure 5. Moreover, the average concentration profile obtained from the application of a diffusion-reaction model to this case (Lopes, 1997) points out the existence of a completely penetrated biofilm (Figure 6).

\section{Conclusions}

The main conclusions are as follows:

1. The high exopolymer production detected in the early phase of biofilm formation is important for promoting cell adhesion and biofilm cohesion in high shear stress and abrasive conditions.

2. In the conditions of this experiment it appeared that the proteins measured in the biofilm were mainly intracellular.

3. Biofilm development resulted in an increase of its activity as measured by surface glucose reaction rate $\left(r_{f a}\right)$ and specific glucose removal rate $\left(q_{S}\right)$. At the end of the experiment, the specific biological activity decreased. This is explained by a reduction in the cell density inside the biofilm instead of a loss of biological activity, as confirmed by the average substrate concentration profile determined by a diffusion-reaction model applied to the data.

\section{Acknowledgement}

The authors acknowledge the financial support of programme Praxis XXI (Grant Praxis XXI/BM/6699/95).

\section{References}

Azeredo, J., Oliveira, R. and Lazarova V. (1998). A new method for extraction of exopolymers from activated sludges. Wat. Sci. Tech., 37(4-5), 367-370.

Dubois, M., Gilles, K.A., Hamilton, J.K., Rebers, P.A. and Smith, F. (1956). Colorimetric method for determination of sugars and related substances. Analyt. Chem., 28, 350-355.

Heijnen, J. J., van Loosdrecht, M. C. M., Mulder, A. and Tijhuis, L. (1992). Formation of biofilms in a biofilm airlift suspension reactor. Wat. Sci. Tech., 26(3-4), 647-654.

Lopes, F. A. (1997). Characterisation and activity of Pseudomonas fluorescens biofilms in an airlift reactor. Master of Science thesis (in Portuguese), Centro de Engenharia Biológica, IBFQ, University of Minho.

Lowry, O., Rosebrough, N.J., Farr, A.L. and Randall, R.J. (1951). Protein measurement with the Folin phenol reagent. J. Biol. Chem., 193, 265-275.

Tijhuis, L., van der Pluym, L.P.M., van Loosdrecht, M.C.M. and Heijnen, J.J. (1992). Formation of biofilms on small suspended particles in airlift reactors. Wat. Sci. Tech., 26(9-11), 2015-2019.

Tijhuis, L., van Loosdrecht, M.C.M. and Heijnen, J.J. (1994). Formation and growth of heterotrophic aerobic biofilms on small suspended particles in airlift reactors. Biotechnol. Bioeng., 44, 595-608. 